Assemblages of phytoplankton pigments

along a shipping line through the North Atlantic and Tropical Pacific

By : Yves Dandonneau ${ }^{(1)}$ and Awa Niang ${ }^{(2)}$

(1) IRD, IPSL/LOCEAN (CNRS, IRD, MNHN, UPMC), 4 place Jussieu, 75252 Paris cedex 05, France

(2) LTI/ESP, Université Cheik Anta Diop, Dakar, Sénégal

(keywords : photosynthetic pigments, phytoplankton, seasonal variability, equatorial currents, north Atlantic, tropical Pacific)

Corresponding author: Yves Dandonneau

e-mail : yves.dandonneau@locean-ipsl.upmc.fr tel : 33144274765 fax : 33144273805

address : LOCEAN, Université Pierre et Marie Curie, 4 place Jussieu, 75252 Paris cedex 05, France 


\begin{abstract}
A set of phytoplankton pigments measurements collected on eight quarterly transects from France to New Caledonia is analyzed, in order to identify the main assemblages of phytoplankton, and to relate their occurrence with oceanic conditions.
\end{abstract} Pigments concentrations are first divided by the sum monovinyl chlorophyll $a$ plus divinyl chlorophyll $a$ to remove the effect of biomass, and, second, normalized, to give an equal weight to all pigments. The resulting 17 pigments $\times 799$ observations matrix is then classified into ten clusters using neural methodology. Eight out of these ten clusters have a well marked regional or seasonal character, thus evidencing adapted responses of the phytoplankton communities. The main gradient opposes two clusters with high fucoxanthin and chlorophyll $c_{1+2}$ in the north Atlantic in January, April and July, to three clusters in the South Pacific Subtropical Gyre with high divinyl chlorophyll $a$, zeaxanthin and phycoerythrin. One of the clusters in the South Pacific Subtropical Gyre has relatively high zeaxanthin and phycoerythrin contents and dominates in November and February (austral summer) while another one, with relatively high divinyl chlorophylls $a$ and $b$ dominates in May and August (austral winter). The third one in this area is characterized by high carotene concentration and its occurrence peaks in February and May. In the equatorial currents system, one cluster, rich in chlorophylls $b$ and $c_{1+2}$, is strictly located in a narrow zone centred at the equator, while another one, with relatively high violaxanthin concentration, is restricted to the high nutrient low chlorophyll waters in only the southern part of the South Equatorial Current. One cluster with relatively high prasinoxanthin content has a spatial distribution that spans the entire South Equatorial Current. Two clusters have a ubiquitous distribution: one in the equatorial Pacific, in the Carribbean Sea and in the north Atlantic in summer has pigments concentrations that are close to the average of the entire dataset, and the other one in the South Pacific Subtropical Gyre, in the Carribbean Sea and in the north Atlantic in autumn clearly has an oligotrophic character. Many of the differences between clusters are caused by 
diagnostic pigments of nano or pico flagellates. While the space and time characteristics of the clusters are well marked and might correspond to differences in physical and chemical forcing, knowledge of the ecological requirements of these flagellates is generally lacking to understand how the variability of the environment triggers these clusters. 


\section{I.- INTRODUCTION}

Representing marine primary production in models is a major challenge to understand the evolution of climate, as it is one of the processes which drive the greenhouse gas carbon dioxide from the atmosphere into the deep ocean. Photosynthesis depends for a large part on chlorophyll concentration, which is now monitored through the remote sensing of sea color (Antoine et al., 1996). However, the phytoplankton is composed of thousands of species, many of them having different consequences on the ocean biogeochemistry. They differ according to their capacity to assimilate nitrate, leading to new production, rather than ammonium leading to regenerated production (Dugdale and Goering, 1967). Where iron is available, blooms of diatom often cause intense fluxes of particulate carbon to the abyss (Romero et al., 1999) while in iron-limited oligotrophic waters, Prochlorococcus often dominates and grows essentially on regenerated nitrogen, so that its role in carbon export to depth is very small (Partensky et al., 1999b). The coccolithophorids build calcium carbonate pieces and thus carry out a flux of particulate inorganic carbon (Holligan et al., 1993; Fernandez et al., 1996), while Trichodesmium is able to assimilate nitrogen in the $\mathrm{N}_{2}$ form to fulfil its nitrogen requirements (Capone et al., 1997). The carbon to nitrogen ratio (as well as other ratios) in organic matter exported to depth has been found to vary much more than one could expect when the Joint Global Ocean Flux Study (JGOFS) international program was initiated in the early nineties. All of this is largely caused by the variability of populations that carry out the biogeochemical fluxes. The efficiency of many groups of algae to sink organic carbon in the ocean is generally poorly known. In addition, it is likely that phytoplankton assemblages have an impact on zooplankton populations, and on the export of organic particles to depth (Calbet and Landry, 1999). 
Thus, the sole knowledge of chlorophyll $a$ distribution, which is a variable in simple biogeochemical models, is insufficient to assess the carbon fluxes in the ocean. Coupled physical-biogeochemical models now tend to use more and more complex ecosystems (Aumont et al., 2003; Le Quere et al., 2005; Hood et al., 2006; Litchman et al., 2006), in order to better represent the diversity of the impact of plankton functional groups on oceanic fluxes of matter. However, qualitative field data to validate these models, are very scarce, and there is a need to enhance our knowledge on the mechanisms which favour some phytoplankton species rather than other ones. The tools to observe phytoplankton populations are still very imperfect. Most nano- and picoplanktonic species can hardly be identified routinely by microscopy. However, some of the photosynthetic pigments are characteristic of phytoplankton groups (while often not strictly, and in variable amounts), so that quantitative pigments inventories reflect the natural assemblages of algal groups.

We describe here the variability of pigment assemblages using data collected along a shipping track from Europe to the south-western Pacific on 8 quarterly transects from 2000 to 2002 and we attempt to relate this variability to the large scale variations of environmental parameters. In a previous work (Dandonneau et al., 2006), these data have been used to study the variability of the phytoplankton biomass and of some photosynthetic pigments inside $a$ priori defined ecological provinces (Longhurst, 1998), in relation with environmental parameters. In the present work, the pigments from this field experiment are considered altogether, regardless of their time or space provenance. The objective is to identify assemblages that best represent the variability of the whole pigments dataset. Such assemblages might reflect phytoplankton assemblages, and to some extent, pelagic ecosystems. Each of them can be supposed to exert a specific effect on marine biogeochemistry, whatever its biomass and the region where it grows are. Then, we examine how they respond to environmental conditions. These data come from a wide variety of 
regions, thus potentially giving a global significance to this study. They are first classified into homogeneous groups of observations, and then the differences between these groups are discussed. Ancillary nutrient and temperature data are used to investigate how environmental conditions may impact the phytoplankton composition.

The 8 cruises were part of the GeP\&CO project (Geochemistry, Phytoplankton and Color of the Ocean : http://www.lodyc.jussieu.fr/gepco/gepco.html) coordinated by the PROOF (Processus Océaniques et Flux) French national programme. Financial support was from the Institut National des Sciences de l'Univers / Centre National de la Recherche Scientifique (INSU/CNRS), from the Institut de Recherche pour le Developpement (IRD), and from the Centre National d'Etudes Spatiales (CNES).

\section{II.- MATERIAL AND METHODS}

The GeP\&CO field data have been collected on the shipping line from Le Havre (France) to Nouméa (New Caledonia) via New York, Panama, Tahiti and Auckland. There were 12 cruises, 4 each year in January-February, April-May, July-August and OctoberNovember. Due to changes in the HPLC equipment and standards after the third cruise (especially the addition of alloxanthin in the pigments standards and analysis of chromatograms), we did not consider the first year and only cruises 5 to 12 are used here. Scientific observers onboard ensured the underway sampling for nutrients measurements and for the filtrations for pigments determinations at 6:00, 10:00, 14:00, 18:00 and 22:00 (local time). Seawater samples were collected at the seawater intake of the engine's cooling system, at a depth of approximately $5 \mathrm{~m}$. 


\section{II.1.- Pigments measurements}

All pigments measurements were made in the laboratory after each cruise. Meanwhile, filters were kept frozen onboard at $-80^{\circ} \mathrm{C}$ during 45 to 85 days. Dry ice was used during transport from the ship to the laboratories. In all cases, filtration pressure did not exceed 0.25 atmospheres. Spectrofluorometry was used to measure the concentration of chlorophyll pigments and to estimate phycoerythrin at LOCEAN in Paris. HPLC instrumentation at the Station Marine d'Arcachon was used for the analysis of chlorophyll and carotenoid pigments. There was an overall agreement between spectrofluorimetric and HPLC determinations of chlorophyll pigments. Both methods gave similar monovinyl + divinyl chlorophyll concentration, but our HPLC technique failed to properly separate the monovinyl and divinyl forms of chlorophyll $a$ and $b$ (Dandonneau et al., 2006). Consequently, for chlorophylls, we retained here the results obtained by spectrofluorometry, which efficiently separates these forms. Abbreviations of pigment names are given in Table 1.

\section{II.1.1.- Spectrofluorimetric determinations of chlorophyllous pigments}

Filtrations $(500 \mathrm{~mL})$ were made with $25 \mathrm{~mm}$ Whatman GF/F filters. The filters were then hand-ground in a glass tube with $6 \mathrm{ml}$ of $90 \%$ acetone using a glass stick. Extraction was allowed overnight in the same tube at $5^{\circ} \mathrm{C}$ in the dark. Prior to measurement, extracts were centrifuged at $6000 \mathrm{rpm}$ for 10 minutes. The method was calibrated versus standards purchased at DHI, Denmark (monovinyl chlorophyll $a$, monovinyl chlorophyll $b$, chlorophyll $c_{1+2}$, chlorophyll $c_{3}$, divinyl-chlorophyll $a$ ). Pure divinyl chlorophyll $b$ was provided by 
Jacques Neveux. Pheophytin $a$ standards were also purchased from DHI, while the other pheopigments were obtained after acidification of the acetonic solution of standards.

The principle of the spectrofluorometric method is to compute the coefficients (i. e. concentrations) that minimize the sum of squares of deviations between the measured fluorescence of extracts and a linear combination of the fluorescence of 12 pigments standards, namely $\mathrm{Chl} a, \mathrm{Chl} b, \mathrm{Chl} c_{1+2}, \mathrm{Chl} c_{3}, \mathrm{DV} \operatorname{chl} a, \mathrm{DV} \operatorname{chl} b$, and all corresponding pheopigments (Neveux and Lantoine, 1993). A thirteenth pigment is added, with a flat excitation-emission fluorescence spectrum, which accounts for the turbidity of the extract. Fluorescence measurements were made at excitation wavelengths from 390 to $480 \mathrm{~nm}$ (at 3 nm intervals), and emission from 620 to $720 \mathrm{~nm}$ (at $4 \mathrm{~nm}$ intervals), yielding 806 values. The numerical solution sometimes gives negative concentrations for some pigments at vanishing concentration (especially the pheopigments). In such cases, computation was made again, with the excitation-emission fluorescence spectrum of the corresponding standard discarded, until all concentrations found were positive.

\section{II.1.2.- HPLC determinations of carotenoid pigments}

The method we used was adapted from Goericke and Repeta (1993). Details can be found on http://www.lodyc.jussieu.fr/gepco/gepco.html. Filtration onto $25 \mathrm{~mm}$ Whatman GF/F filters was stopped after $1 \mathrm{~h}$. Filtered volume was generally around $2 \mathrm{~L}$ in offshore seawater. Extraction was $1 \mathrm{~h}$ long at $4^{\circ} \mathrm{C}$ in $2 \mathrm{~mL}$ of methanol after sonication. Pigment elution was achieved with a decreasing proportion of ammonium acetate and an increasing proportion of methanol, with a total runtime of 40 minutes. The method was calibrated with standards purchased from DHI, Denmark $\left(\mathrm{Chl} c_{3}, \mathrm{Chl} c_{1+2}\right.$, Perid, But-fuco, Fuco, Hex-fuco, Pras, Viola, Diadino, Allo, Zea, DV chl $b, \mathrm{Chl} b, \mathrm{DV} \operatorname{chl} a, \mathrm{Chl} a$, and $\beta \beta$-car). As said 
above, our HPLC technique did not separate accurately DV chl $a$ from $\mathrm{Chl} a$. This might be caused by our HPLC column which was not exactly the same as that recommended in the reference method.

\section{II.1.3.- Spectrofluorometric determinations of phycoerythrin}

Phycoerythrin is present in the open sea primarily in the cyanobacteria, and also in cryptophytes which often make blooms in coastal areas. It is fluorescent but does not dissolve in acetone nor methanol, and is thus rarely estimated routinely. Its measurement necessitates filtration, after which it can be extracted, with variable efficiency, in a glycerol-phosphate buffer (Lantoine and Neveux, 1997). To avoid this uncertain extraction step, Wyman (1992) proposed an in vivo fluorescence technique, in which the cells were first concentrated on a filter, then washed off using a small water volume, and finally concentrated by centrifugation. In this technique, fluorescence measurements are made after addition of glycerol, in order to block the transfer of excitation energy from phycoerythrin to photosystem II. Indeed, this transfer, which is dependent on the physiological state of the cells, has a strong and variable quenching effect on the fluorescence yield of phycoerythrin. Due to the constraints of the GeP\&CO experiment, we could not apply this methodology, and we used a simple procedure, in which the fluorescence of phycoerythrin was measured without extraction, as in Wyman (1992), but directly on the filter. Seawater $(100 \mathrm{~mL})$ was filtered onto $13 \mathrm{~mm}$ Millipore cellulose acetate $\mathrm{HA}$ black filters and stored at $-80^{\circ} \mathrm{C}$. Back in the laboratory, the filters were brought to ambient temperature, immersed in $200 \mu \mathrm{L}$ of seawater (taken from standards for salinity measurements), fixed in a vertical position between two quartz prisms, and exposed at $\pi / 4$ radians to the lamp and photomultiplier of a spectrofluorometer. Attempts to add glycerol did not result in an increase of fluorescence, suggesting that the transfer of excitation energy 
to photosystem II had been disrupted during storage. Fluorescence measurements were made at excitation wavelengths from 384 to $576 \mathrm{~nm}$ (at $8 \mathrm{~nm}$ intervals), and emission from 500 to $730 \mathrm{~nm}$ (at $10 \mathrm{~nm}$ intervals), and the computing procedure yielded coefficients that minimized the sum of squares of differences between these fluorescence measurements and a linear combination of four excitation emission fluorescence patterns. These patterns were (1) the instrumental response of a blank filter, (2) the fluorescence of photosystem II, (3) the fluorescence of phycourobilin chromophore of phycoerythrin (PUB), and (4) the fluorescence of phycoerythrobilin chromophore of phycoerythrin (PEB). The two latter patterns were obtained from cultures of two strains of the cyanobacterium Synechococcus sp., one with high PUB/PEB ratio and one with a low ratio. One difficulty with this method came from scatter of light by the "grey" membrane filter which dominated the fluorescence signal when excitation and emission wavelengths were close to each other. Indeed, in such cases, the spectrum of light scattered by the filter overlapped the spectrum of the instrument's emission monochromator, resulting in a high blank and noise. Maximum PUB fluorescence occurs with excitation at $490 \mathrm{~nm}$ and emission at $565 \mathrm{~nm}$ (separated by $75 \mathrm{~nm}$ ), while for PEB, maximum fluorescence occurs with excitation at $540 \mathrm{~nm}$ and emission at $580 \mathrm{~nm}$ (separated by only 40 $\mathrm{nm}$ and yielding large uncertainties). Consequently, only the PUB fluorescence pattern was used here to estimate the concentration of phycoerythrin, and at this stage, units are arbitrary. This has a limited impact on the conclusions derived from this approach since the PUB to PEB ratio is quite stable at 1.9 (Lantoine and Neveux, 1997) in surface mesotrophic and oligotrophic waters, which dominate in the GeP\&CO dataset.

\section{II.2. Ancillary measurements}


Temperature and salinity data were acquired with a SEABIRD thermosalinograph located at the seawater intake of the engine's cooling system. At each observation, seawater samples were stored in $50 \mathrm{~mL}$ glass tubes for nutrient analysis (silicate, nitrate + nitrite, and phosphate), and in $1.5 \mathrm{~mL}$ cryotubes for flow cytometry counts of picoplankton (Prochlorococcus, Synechococcus, picoeucaryotes, and heterotrophic bacteria), poisoned respectively with mercury chloride and glutaraldehyde. Details on these methodologies are given in Dandonneau et al. (2006).

\section{II.3.- Clustering of the observations}

In the domain investigated during $\mathrm{GeP} \& \mathrm{CO}$, the phytoplankton pigment biomass varies by nearly two orders of magnitude between the chlorophyll rich North Atlantic in spring, and oligotrophic waters of the subtropical south Pacific. Here, we are interested in the relative variations of algal groups in the phytoplankton populations, rather than in the distribution of total phytoplankton biomass. Hence, emphasis is put equally on all pigments, whatever they are usually abundant or scarce, and the unwanted effect of biomass must be removed. For this goal, the so-called pigments ratios obtained by dividing each pigment concentration by the Chl $a$ concentration (Mackey et al., 1996) may indeed remove the biomass effect. However, such pigments ratios have infinite values for genus Prochlorococcus which has no Chl $a$, but instead DV chl $a$. This may strongly impact this study since the GeP\&CO observations include many samples taken in tropical oligotrophic waters where Prochlorococcus dominates. We thus considered that the sum chlorophyll $a+\operatorname{divinyl}$ chlorophyll $a$ (TChla) was an indicator of the biomass of the photosynthetic population, and for each observation, we divided the pigment concentrations by this sum (note that after this transformation, "biomass-free" TChla is is equal to 1 for all observations, and "biomass-free 
DV chl $a$ " can be deduced from the knowledge of "biomass-free Chl $a$ "). The resulting dataset would still be confounded by the fact that some pigments, that may be of interest because they are indicators of phytoplankton groups, occur only at low concentrations (for instance : Pras for Prasinophytes, Allo for Cryptophytes) while other ones are abundant everywhere (Chl $a, \mathrm{Chl} c_{1+2}$, Hex-fuco) and would mask the variance of less abundant accessory pigments. In order to allocate an equal weight to all pigments, we thus further normalized the concentration of each pigment so that its average concentration for all observations be null, and standard deviation be 1, as is often done in principal component analysis softwares.

The resulting matrix consisted of approximately 1120 observations $\times 23$ dimensionless twice-normalized pigments concentrations (further denoted by an asterix), representing 8 cruises, i. e. four seasons during two years (October 2000 to August 2002). The pheopigments data were not included since these pigments are not found in healthy phytoplankton. Further, we randomly subsampled the observations, to reserve about one third of the observations to validate the classification. The resulting 799 observations $\times 17$ pigments* matrix was first summarized into a discrete set of formal neurons ( 9 x 9) and their associated referent vectors, using the Self Organizing Map model developed by Kohonen (1984) for visualising and clustering high dimensional data sets. Each observation was captured by the closest neuron. Finally, a hierarchical ascendant clustering was applied to the neurons to obtain a reasonable number of clusters, each one corresponding to a group of closely resembling observations, as in Niang et al. (2003). For this clustering, the distances between observations were computed according to probabilities while the most widespread techniques are based on inertia. This however had very little impact on the final results. The desirable number of clusters must be initially specified. Intuitively, this number must be larger than 3, but should not exceed 15 . We made several attempts by applying a hierarchical clustering to the set of reference vectors. 
All gave clusters with coherent geographical distribution, but small numbers resulted in clusters that were too ubiquitous and could not be firmly associated with specific regimes. Finally, with the number of clusters set to 10, the unsupervised classification returned well organized clusters in terms of time and space distribution.

\section{III.- RESULTS}

Five out of the ten clusters that resulted from the probabilistic self organizing map (clusters \#2, \#3,\#4, \#8 and \#9) occurred strictly in tropical zones (Figure 1). Two were found mostly in the temperate north Atlantic (clusters \#6 and \#10). Cluster \#5 was dominantly a tropical one, but was also found frequently at about $30^{\circ} \mathrm{S}$ near New Zealand, as well as cluster \#7, which also occurred in the north Atlantic in boreal autumn. The ubiquitous cluster \#1 occurred both in the subtropical and equatorial Pacific, in the Carribbean Sea and in the temperate north Atlantic. The balance between Chl $a$ and DV chl $a$ was responsible for most of the differences between clusters. It introduced a marked difference between the Chl $a$-rich north Atlantic (clusters \#6, \#10, and, to a lesser extent, \#1) and DV chl $a$-dominated waters in clusters \#5, \#7, \#8 and \#9 (Table 2). This transition from eutrophic or mesotrophic waters to oligotrophic ones appears clearly on a dendrogram (Figure 2), in which the close vicinity of pigments assemblages in the nutrient-rich north Atlantic and equatorial Pacific is obvious. Generally, the clusters show a strong affinity for a given space and time domain in which the majority of its observations are found, and some sparse points in some other domains. Given these affinities, the clusters are further designated and abbreviated as follows :

- Cluster \#1, Undefined Mesotrophic (\#UM)

- Cluster \#2, South Pacific Subtropical Gyre in austral Summer (\#SGS)

- Cluster \#3, Equatorial Upwelling (\#EU)

- Cluster \#4, South Equatorial Current (\#SEC) 
- Cluster \#5, South Pacific Subtropical Gyre (\#SG)

- Cluster \#6, North Atlantic - Winter to Summer (\#NAWSu)

- Cluster \#7, Undefined Oligotrophic (\#UO)

- Cluster \#8, Southern Branch of South Equatorial Current (\#SBSEC)

- Cluster \#9, South Pacific Subtropical Gyre in austral Winter (\#SGW)

- Cluster \#10, North Atlantic - Winter to Spring (\#NAWSp)

An examination of the variability of the relative abundance of each pigment in all clusters reveals which pigments respond to habitat variability. $\mathrm{Chl} b^{*}$ was the most variable among the accessory pigments (Table 2), being at more than $50 \%$ higher than its average relative concentration in the equatorial Pacific (\#EU, \#SEC and \#SBSEC), and at less than 50\% lower south of this area, in the south Pacific subtropical gyre (\#SGS, \#SG, \#UO and \#SGW). DV chl $b^{*}$ was abundant in \#SG and \#SGW, and at low concentrations in the equatorial Pacific (\#EU and \#SBSEC) and in the north Atlantic (\#NAWSu and \#NAWSp). Chl $c_{1+2} *$ was higher than its relative average in the equatorial Pacific and in the north Atlantic (\#EU, \#NAWSu and \#NAWSp), and lower in \#SGS, \#SG, \#UO and \#SGW. Chl $c_{3}^{*}$ and But-fuco* characterized only \#NAWSu where they occurred at relatively high concentrations. Fuco marked the temperate north Atlantic (\#NAWSu and \#NAWSp) and was very low in \#SGW. Hex-fuco* did not exhibit large differences between clusters, except in the Pacific, south of the equator (\#SBSEC). Pras* occurred noticeably only in \#SEC, Viola* in \#SBSEC, and Allo* in \#NAWSp. Zea* was abundant in \#SGS, \#SG and \#SGW, and was low in the north Atlantic (\#NAWSu and \#NAWSp). $\beta \beta$-car* was also at relatively low concentrations in the same north Atlantic clusters, and at high concentrations in \#SG and \#UO. High relative concentrations of Phycoer* occurred in \#SGS and \#SGW, and low values were observed in clusters \#NAWSu and \#NAWSp of the north Atlantic. Average relative normalized 
concentrations of the two remaining pigments (Perid* and Diadino*) were in no case lower than -0.5 or higher than 0.5 , giving these pigments a low weight in this classification.

The ten clusters are generally located in well defined areas and, often, seasons (Figure 1). The space and time location, main pigment characteristics, and inferred populations trends of all ten clusters are listed in Table 3.

\#UM is the most ubiquitous of all ten clusters, and contained 134 observations from high as well as from low latitudes in both hemispheres, collected mostly in July-August and October-November. They were found sparse all along the GeP\&CO track, in the north Atlantic, Carribbean Sea and Tasman Sea in January-February, Carribbean Sea and equatorial Pacific in April-May, and almost everywhere in July-August and October-November. Normalized pigments concentrations in this cluster did not depart markedly from the overall average (Table 2). Its most noticeable pigments feature was the dominance of Chl $a^{*}$ over DV $\operatorname{chl} a^{*}$. The distribution of all ancillary properties is close to that in the entire GeP\&CO dataset (Table 4).

\#SGS is remarkably focused on the South Pacific Subtropical Gyre in austral summer (cruises in January-February and October-November). Only 5 out of its 61 samples were taken in austral winter (Figure 1). Specificity of this cluster is mostly due to highest values of Phycoer* and Zea*, and low values of $\mathrm{Chl} b^{*}$ and $\mathrm{Chl} c_{21+2} *$ (Tables 1 and 2). Its observations had low TChla, low nutrients, and low picoplankton counts (Table 4).

The 60 observations in \#EU were located near the equator at all seasons, except 7 from the north Atlantic in northern autumn and 3 near New Zealand in July-August and OctoberNovember (Figure 1). They were characterized by relatively high $\mathrm{Chl} b^{*}$ and $\mathrm{Chl} c_{1+2}{ }^{*}$, and low DV chl $b^{*}$ and Phycoer* (Tables 2 and 3). They corresponded to TChla ranging between 
0.1 and $0.3 \mu \mathrm{g} \mathrm{L}^{-1}$, relatively high picoeucaryotes at the expense of Prochlorococcus, highest nutrient concentrations and sea surface temperature generally greater than $23^{\circ} \mathrm{C}$ (Table 4 ).

\#SEC (99 observations) has a space and time distribution very similar to that of \#EU, but is not strictly restricted to the equatorial band (Figure 1). Some samples in this cluster were from the Carribbean Sea and the vicinity of New Zealand, and from the north Atlantic in October-November. In October-November and January February, its observations near the equator extended south-westwards to $14^{\circ} \mathrm{S}$ near Tahiti. Normalized pigment concentrations in this cluster did not depart widely from the global average, except $\mathrm{Chl} b^{*}$ and Pras*, the average of which exceeded 0.5 (Table 2). Nutrient concentrations were moderately high and sea surface temperature was generally greater than $24^{\circ} \mathrm{C}$ (Table 4).

\#SG (82 observations) was mostly present in the south-western tropical Pacific in January-February and October-November. Some of its observations were also collected in the Carribbean Sea and in the north Atlantic in October-November (Figure 1). It is characterized by high DV $\operatorname{chl} a^{*}$ and DV $\operatorname{chl} b^{*}$. It has low Chl $c_{1+2}{ }^{*}$, high Zea*, and highest record of $\beta \beta$ car*. Similar to \#SGS, ratios of picoeucaryotes, and especially Prochloroccus (highest record) to TChla were high, while Synechococcus/Tchla was low. Nutrient concentrations were low, and sea surface temperature was high (Table 4).

Most of the 95 observations of \#NAWSu were located in the north Atlantic, a few ones being right at the equator at all seasons or near New Zealand in winter (July-August and October-November) (Figure 1). Chl $a^{*}, \mathrm{Chl} c_{1+2}{ }^{*}$ and $\mathrm{Chl} c_{3}{ }^{*}$ were relatively high in this cluster, as well as Fuco* and But-fuco*. DV chl $a^{*}$ and DV chl $b^{*}$ were low, as well as Phycoer* and the photoprotectant pigments Zea* and $\beta \beta$-car* (table 2). All picoplankton groups were low relatively to TChla ; nutrients were high, and sea surface temperature was low (Table 4). 
\#UO (57 observations) was found in the Carribbean Sea in January-February, in the southwestern tropical Pacific in April-May and July-August, and in the north Atlantic in October-November (Figure 1). Its pigments composition resembled that of \#SG, with however less DV chl $b^{*}$ and less Zea* (Table 2). The three categories of picoplankton behave differently in this cluster: abundances of picoeucaryotes, Synechococcus and Prochlorococcus were low, medium and high, respectively. Nutrients were low and sea surface temperature was high (Table 4).

\#SBSEC has 82 observations that were astonishingly focused on the South Equatorial Current between $\sim 3^{\circ} \mathrm{S}$ and $\sim 12^{\circ} \mathrm{S}$ (Figure 1). These observations had low Chl $a^{*}$ and high DV chl $a^{*}$, and reversely, high $\mathrm{Chl} b^{*}$ and low DV chl $b^{*}$. They also had high Hex-fuco* and high Viola* (Table 2). If divided by TChla, the abundance of all three picoplankton categories was higher in this cluster than in the whole data set average. Nutrients were high, and sea surface temperature was the highest in the GeP\&CO record (Table 4).

\#SGW (64 observations) occupied the South Pacific Subtropical Gyre in austral winter (April-May and July-August). Thus, it complements \#SGS whose observations were in the same area, but in the summer months (Figure 1). It is characterized by low Chl $a^{*}, \mathrm{Chl} b^{*}$ and Chl $c_{1+2}$, and high DV chl $a^{*}$ and DV chl $b^{*}$, low Fuco* and high Zea* and Phycoer* relatively to TChla (Table 2). It had few picoeucaryotes and Synechococcus but Prochlorococcus numbers were higher than the average. Nutrients were at low concentrations in this cluster, especially nitrate + nitrite, and sea surface temperature was high (Table 4).

The north Atlantic in northern winter and spring contains most of the 76 observations captured by \#NAWSp, except one observation right at the equator and three in the Gulf of Panama in April-May, one right at the equator, one near Tahiti and eight in the north Atlantic in July-August, and three in the Channel and Gulf of Biscay in October-November (Figure 1). Observations in this cluster had highest normalized concentration of Fuco* and Allo*, high 
Chl $c_{1+2}{ }^{*}$, and low DV chl $a^{*}$, DV Chl $b^{*}, Z^{*}$, $\beta \beta$-car*, and Phycoer* (Table 2). They also had highest TChla concentrations, highest picoeucaryotes and Synechococcus numbers and lowest Prochlorococcus numbers (Table 4). Nutrient concentrations were higher than the GeP\&CO average (but lesser than in the equatorial Pacific \#EU) and sea surface temperature was lowest.

\section{IV.- DISCUSSION}

The pigments observations made during the GeP\&CO experiment differed mostly by their DV chl $a$ to TChla ratio. Clusters in which this ratio was high had phytoplankton populations dominated by Prochlorococcus spp., the only genus that contains DV $\operatorname{chl} a$, and thus corresponded to oligotrophic waters (Partensky et al., 1999a; Mackey et al., 2002). Inversely, those with a low ratio corresponded to temperate or colder waters, generally rich in nutrients and in Chl $a$, where Prochlorococcus does not dominate or even is absent. \#UM, \#NAWSu and \#NAWSp include many observations from the north Atlantic, and also from the south Pacific near New Zealand, and from the equatorial upwelling in the Pacific Ocean. Oppositely, \#SG, \#UO, \#SBSEC and \#SGW correspond to the South Pacific Subtropical

Gyre, and, for a few observations, to the temperate north Atlantic in autumn (Figure 1). Along with this gradient from oligotrophic to productive waters, the relative zeaxanthin concentration tended to decrease while that of $\mathrm{Chl} c_{1+2}, \mathrm{Chl} c_{3}$, and Fuco, tended to increase. Thus, the contribution of DV chl $a$ and zeaxanthin bearing cyanobacteria to total phytoplankton generally increases when the oligotrophic character of water masses is asserted, as previously described by Gibb et al. $(2000,2001)$ in the Atlantic Ocean.

\section{IV.1.- The north Atlantic}


Examining the ten clusters beyond this first order difference between mesotrophic and oligotrophic waters leads to some interesting new features. \#NAWSp which mostly contains observations from the north Atlantic in winter and spring (Figure 1) is the cluster in which Fuco had the highest relative concentrations (Table 2). Observations in \#NAWSu also had high Fuco* (Table 3), in the same area and at the same seasons as \#NAWSp, and, additionally, in summer (Figure 1). In these two clusters, relatively high Fuco marks the diatom bloom that occurs each year in the north Atlantic (Barlow et al., 1973). Both had high TChla and nutrient levels, and low sea surface temperature (Table 4). They differed mostly by relatively more Viola* and Allo*, and less $\mathrm{Chl} c_{1+2}{ }^{*}$ and $\mathrm{Chl}_{c_{3}}$, Hex-fuco* and But-fuco*, Perid* and Diadino* in \#NAWSp than in \#NAWSu (Figure 3). Phycoer in \#NAWSu had a higher phycourobilin to phycoerythrobilin ratio than in \#NAWSp (data not shown). The lower salinity in cluster \#NAWSu than in \#NAWSp, and persistence of \#NAWSu trough summer suggests that it marks the polar north Atlantic waters, in which the bloom appears later than in the Gulf Stream drift waters (Longhurst, 1998; Dandonneau et al., 2006). These drift waters are better represented by \#NAWSp.

A tentative diagnostic of the phytoplankton groups in the north Atlantic GeP\&CO observations using CHEMTAX (Mackey et al., 1996), initiated with the pigments ratios characteristic of the Antarctic and modified to account for DV chl $a$, indicates that chlorophytes (47\%) dominated the phytoplankton biomass, followed by haptophytes $(27 \%)$, Synechococcus (7\%), prasinophytes (7\%), diatoms (4\%), dinoflagellates $(4 \%)$, and

\section{Prochlorococcus (2\%).}

The large time and space overlap of the two clusters may be an effect of the many eddies that characterize this region and interpenetrate Gulf Stream drift waters and colder waters from the north. Pigments differences indicate that the polar north Atlantic waters 
(\#NAWSu) have more dinoflagellates (Perid* and $\mathrm{Chl} c_{1+2}{ }^{*}$ ) haptophytes and chrysophytes $\left(\mathrm{Chl} c_{3}{ }^{*}\right.$, Hex-fuco* and But-fuco*), and less cryptophytes (Allo*) than the Gulf Stream waters according to commonly accepted pigment criteria (Jeffrey and Vesk, 1997; Gibb et al., 2001). Relatively high Diadino* in \#NAWSu is consistent with the role played by this pigment in the xantophyll-cycle in dinoflagellates and haptophytes. Interestingly, \#NAWSu includes a few observations right at the equator in the Pacific (figure 1), i. e. in a region where the occurrence of diatoms has often been reported (Blain et al., 1999; Kobayashi and Takahashi, 2002; Latasa et al., 1997), but where massive diatoms blooms are scarce (Chavez, 1989). \#UM, \#SEC and \#UO also included some observations in the north Atlantic in summer and autumn (Figure 1). They had less Fuco* than \#NAWSu and \#NAWSp observations, corresponding to the oligotrophic conditions that prevail after the spring bloom of diatoms.

\section{2.- The South Pacific Subtropical Gyre}

The South Pacific Subtropical Gyre between Tahiti and New Zealand is best represented in three clusters : \#SGS, \#SG and \#SGW (Figure 1). According to CHEMTAX attempts, initiated with the pigments ratios characteristic of the equatorial Pacific (Mackey et al., 1996), this area was always dominated by Prochlorococcus (39\%), Synechococcus (27\%), haptophytes (19\%) and cryptophytes (15\%). Other groups had a very low contribution : diatoms (2\%), dinoflagellates (1\%) and prasinophytes (1\%). Interestingly, \#SGS and \#SGW are found in exactly the same area, but the first one was present in October - November and in January - February (i. e. in the warm austral season), while the second was quasi exclusively found in April - May and in July - August (i. e. the austral winter). These two clusters have in common low $\mathrm{Chl} b^{*}$ and $\mathrm{Chl} c_{1+2}$, and relatively high levels of Phycoer* and Zea* (Table 2). Additionally, \#SGW is marked by high DV chl $a^{*}$ and DV chl $b^{*}$ and by low Fuco*. \#SG differs from cluster \#SGW by less Phycoer* and more $\beta \beta$-car* (Table1). These characteristics 
confirm that the south Pacific subtropical gyre is dominated by cyanobacteria (Table 4), and has few diatoms, chlorophytes, pelagophytes and haptophytes (Jeffrey and Vesk, 1997), as expected in this oligotrophic area (Partensky et al., 1999a). Seasonal alternance of \#SGS and \#SGW might be a response to the variation of solar radiation. In this area, TChla has a weak but clear seasonal cycle that may indeed be a photoadaptative response of the phytoplankton rather than enhanced growth (Dandonneau et al., 2006). Detailed comparison of these two clusters (Figure 4) shows that \#SGS (austral summer) had more Zea* and Phycoer*, and less DV chl $a^{*}$ and DV chl $b^{*}$ than \#SGW (austral winter). High Zea* in summer is consistent with the well-known photoprotectant function of this pigment. In addition, the lower normalized DV chl $a^{*}$ and DV chl $b^{*}$ levels in \#SGS (Figure 4) is a likely response to higher irradiance. Summer \#SGS is also a habitat with the highest Phycoer* values (Table 2). This cannot be explained by photoadaptation since this process tends to decrease the amount of Phycoer per cell at high irradiance (Kana and Glibert, 1987): consequently, an increase in Synechococcus abundance would be a likely explanation. However, flow cytometry counts of picoplankton (Table 4) indicate rather larger numbers of Prochlorococcus (Table 4 and Figure 4) while Synechococcus numbers were low and did not differ between \#SGS and \#SGW (Table 4). Thus, the normalized pigments data and flow cytometry counts of picoplankton give contradictory indications, making it difficult to understand the difference between \#SGS and \#SGW. The presence of phycoerythrin-containing Prochlorococcus strains in summer conditions might explain the increase in both the numbers of Prochlorococcus and Phycoer*. However, such strains are rather considered to be adapted to low irradiance (Penno et al., 2000). A marked decrease in the DV chl $a$ per Prochlorococcus cell under high irradiance might finally provide an acceptable explanation: indeed, under such conditions, the red fluorescence of Prochlorococcus is known to decrease drastically (Dandonneau et al., 2006), indicating a decrease in DV chl a / Prochlorococcus cell at the sea surface. This may account 
for the summer decrease in TChla. After normalization by Tchla, a relative increase in phycoerythrin and zeaxanthin would then result even if abundance of Synechococcus did not change. Thus, the transition from austral winter to summer illustrated by the drastic separation of summer and winter samples in \#SGS and \#SGW would result from photoadaptation rather than from a change of phytoplankton species. A marked increase of heterotrophic bacteria counts in summer (\#SGS) is also noteworthy (Table 4 and Figure 4).

As observed for \#SGS and \#SGW, \#SG also captured many observations from the South Pacific Subtropical Gyre (Figure 1). This cluster had a pigments average composition very close to that of \#SGW, except that it had abundant $\beta \beta$-car* and low Phycoer* (Table 2). It occurred in a wider area which included the Tasman Sea, and spread farther northwards to $14^{\circ} \mathrm{S}$. Some observations in the Carribbean Sea and the north Atlantic in boreal autumn also belong to this cluster. In the South Pacific Subtropical Gyre, it occurred mainly in austral summer and autumn. Observations in \#SG had much more picoeucaryotes, and more nutrients than those in clusters \#SGS and \#SGW. These minor differences make \#SG representative of conditions slightly less oligotrophic than the two former ones.

\section{IV.3.- The equatorial Pacific system}

The zone which corresponds to the South Equatorial Current, from about $13^{\circ} \mathrm{S}$ to $4^{\circ} \mathrm{N}$ is well known as a "high nutrient - low chlorophyll" (HNLC) regime. This HNLC character is attributed to iron limitation and to high grazing pressure all year round (Landry et al., 1997). This region was shared by three clusters: \#EU, \#SEC and \#SBSEC that included observations at all four seasons (Figure 1). \#EU and \#SBSEC are remarkably separated, the first one being restricted to a narrow equatorial band between $5^{\circ} \mathrm{S}$ and $4^{\circ} \mathrm{N}$, while the second is confined into the $1^{\circ} \mathrm{S}$ to $13^{\circ} \mathrm{S}$ band. The area covered by \#SEC merges the two other ones, and also included a few observations in the Carribbean Sea and in the North Atlantic. \#EU and 
\#SBSEC both had high Chl $b^{*}$ content and low DV chl $b^{*}$. In addition, equatorial cluster \#EU had high Chl $c_{1+2}{ }^{*}$ and low Phycoer*, while south equatorial cluster \#SBSEC had a very low Chl $a$ to TChla ratio, and relatively high Hex-fuco* and Viola* levels (Table 2). These two clusters differed markedly in their balance between Chl $a$ and DV chl $a$. \#EU had a lower contribution of DV chl $a$ to TChla, and higher Chl $c_{1+2} *$, But-fuco* and Fuco* (Table 4 and Figure 5), indicating that the upwelling may favour the cryptophytes, the dinoflagellates, haptophytes, pelagophytes, and diatoms (Jeffrey and Vesk, 1997). \#SBSEC in the nitrate-rich South Equatorial Current had relatively high DV chl $a^{*}$, Zea* and Phycoer* (indicative of abundant picoplanktonic cyanobacteria Prochlorococcus and Synechococcus), photoprotectant $\beta \beta$-car*, Viola* and $\mathrm{Chl} b^{*}$ (indicative of chlorophytes and prasinophytes). CHEMTAX tests suggest that \#EU was dominated by haptophytes (39\%) and cryptophytes (29\%), and that $44 \%$ of the biomass in \#SBSEC was due to Prochlorococcus. The higher sea surface temperature in \#SBSEC than in \#EU (Figure 5) is a consequence of the warming of upwelled waters along their drift away from the equator. Average nitrate + nitrite concentration should expectedly be higher in the equatorial upwelling than in the southern branch of the South Equatorial Current, but the difference between the two clusters was small (Table 4). This might be caused by some \#EU observations in autumn which were, in fact, in the north Atlantic (Figure 1), where the nitrate + nitrite concentration is lower than in the equatorial upwelling zone (Dandonneau et al., 2006). Equatorial upwelling of deep waters made \#EU observations less warm than those of \#SBSEC.

The area occupied by \#SEC is the addition of the two former ones, i. e. the South Equatorial Current including the equatorial upwelling (Figure 1). It also includes some observations in the north Atlantic in boreal autumn. This cluster is marked by Pras*, a diagnostic pigment for prasinophytes, and also, like \#EU and \#SBSEC, by Chl $b^{*}$. \#SEC observations had markedly lower nutrient concentrations than those of \#EU and \#SBSEC 
(Table 4), so that it might correspond to older equatorial upwelling waters, in which nutrients removal by the iron limited HNLC ecosystem was more advanced than in the two other ones.

\section{IV.4.- The response of clusters to environmental conditions}

While most clusters closely correspond to restricted space-time domains (Figure 1), these domains overlap slightly. Thus, most observations in the north Atlantic in JanuaryFebruary correspond to \#NAWSu and \#NAWSp, but a few ones belonged to \#UM. In the

same area in April-May, \#NAWSu and \#NAWSp shared all the observations, but the situation was more complicated in July-August, when observations were also captured by clusters \#UM, \#NAWSu, \#SEC, \#UO, \#SGW and \#NAWSu. In October-November, \#SEC and \#UO were dominant, but there were other observations, belonging to \#UM, \#EU, \#SG and \#NAWSu. Finally, only \#SGS (subtropical gyre in austral summer) and \#SBSEC (south equatorial waters) were missing from this large north Atlantic area.

The South Pacific Subtropical Gyre was dominantly associated to \#SGS during the austral summer and \#SGW in winter, but similarly, quite a significant number of observations in this area was captured by other clusters, i. e. \#UM, \#SG and \#UO (Figure 1). \#EU which was restricted to within 4 degrees off the equator (with a few exceptions in the north Atlantic or in the Tasman Sea) shared this zone with \#UM and \#SEC, and, to a lesser extent, with clusters \#NAWSu and \#NAWSp.

Thus, observations in a given area at a given time may often relate to several clusters. This is not surprising since photosynthetic pigments which support this classification characterize taxonomic phytoplankton groups, and because each one of these groups tends to diversify into many species, and colonize the entire world ocean. In addition, water masses are separated by meanders and eddies, rather than by abrupt lines. The GeP\&CO transects 
thus crossed the North Atlantic near the subtropical front, and crossed the equatorial currents system in an area where it is affected by tropical instability waves, that induce mixing between upwelled waters with diverse history and equatorial counter currents waters (Menkes et al., 2002). In spite of these characteristics which tend to temper the differences between phytoplankton populations, two main schemes of variability can be identified in the clusters derived from the GeP\&CO data.

The north Atlantic, which was crossed by the GeP\&CO transects at about $40-50^{\circ} \mathrm{N}$, was occupied in January by populations that were captured by \#NAWSu and \#NAWSp, and for some observations, by the ubiquitous \#UM (Figure 1). In April, it was still populated by \#NAWSu and \#NAWSp . During these winter and spring months, nutrients-rich waters (Table 4) favoured the growth of diatoms which dominated these clusters (Table 3) and were responsible for the spring bloom that peaked in April in the GeP\&CO data (Dandonneau et al., 2006). It is noteworthy that the phytoplankton populations that made this bloom were captured by the same clusters as those observed in January, when the mixed layer was deep and light was limiting. Cluster \#NAWSp tended to disappear from this area in July, replaced by many observations classified into \#UM, denoting a diversification of the phytoplankton populations. Isolated observations closer to the tropical clusters \#SEC, \#UO and \#SGW were indicative of the transition towards summer stratified conditions with a nutrient-exhausted mixed layer. In October, phytoplankton populations in the north Atlantic were similar to those in the tropics, most observations belonging to the mesotrophic clusters \#EU and \#SEC and to the oligotrophic clusters \#SG and \#UO (Figure 1). Some observations in clusters \# NAWSu and \#NAWSp however indicated that, in some areas, the autumn bloom was active. This may be an effect of the variety of ecological conditions offered by the eddies that develop in this area and their interaction with the summer thermocline. 
The second scheme of variability corresponds to the low latitudes where seasonal variations are weak, and the supply of nutrients is controlled by the zonal equatorial currents system. There is a very strong affinity between some clusters and some currents or ocean dynamical processes. Thus, \#EU was remarkably focused on the equatorial Pacific (Figure 1) where upwelling is permanent and nutrients were highest in the GeP\&CO record (Table 4). \#SBSEC was strictly located in the upwelled waters around $5^{\circ} \mathrm{S}$ after their southwest drift from the equator. Farther south, the South Pacific Subtropical Gyre was occupied by oligotrophic waters in which phytoplankton populations were captured by clusters \#SGS, \#SG, \#UO and \#SGW. One may consider that the waters of the southern branch of the South Equatorial Current have drifted south-westwards from the equatorial upwelling. According to the average pigments composition in \#EU and \#SBSEC, this drift resulted in a relative decrease of the diatoms, prymnesiophytes, dinoflagellates, chrysophytes and cryptophytes, and in an increase in prasinophytes (Tables 1 and 2). Farther south, in the subtropical gyre, the populations changed drastically, being dominated by Prochlorococcus and Synechococcus. The equatorial upwelled waters may also evolve into cluster \#SEC whose geographical distribution combines those of \#EU and \#SBSEC (Figure 1). \#SEC has slightly less nutrients than clusters \#EU and \#SBSEC (table 4) and had an average pigments composition close to the overall GeP\&CO average, with however noticeably high relative prasinoxanthin concentration, indicative of a high contribution of prasinophytes to this cluster (table 2 and 3).

This variability with time and/or space is certainly driven by the ocean circulation, nutrients supply and irradiance. Table 4 clearly shows that nitrate concentrations were generally smaller (less than $0.27 \mu \mathrm{M}^{-1}$ ) in clusters \#SGS, \#SG, \#UO and \#SGW, which occupied the south Pacific subtropical gyre, than in the other ones. These are the clusters in which the cyanobacteria Prochlorococcus and Synechococcus dominated. However, in a large 
band across the equator (\#SEC) and in the north Atlantic in winter and spring (\#NAWSu), where nitrate + nitrite concentrations are generally high, $25 \%$ of the nitrate concentrations were less than 0.15 or $0.25 \mu \mathrm{M}$, respectively. Thus, it seems that in these actively growing ecosystems, the phytoplankton populations remain unchanged until complete exhaustion of the available nitrate. As a consequence, the ranges of nutrient concentration largely overlap between clusters, so that the phytoplankton populations cannot be assessed from macronutrients concentrations alone. Iron supply by the equatorial upwelling is a likely cause for the differentiation of phytoplankton populations that correspond to \#EU and \#SBSEC, but the triggering of \#UO vs \#SGS and \#SGW, or \#NAWSp vs \#NAWSu, is not yet well understood. Phytoplankton populations tend to subsist throughout the short term (one or several months) evolution of water masses. This contrasts with the high variability of chlorophyll concentration and demonstrates that large scale sampling experiments such as GeP\&CO are useful to understand how the composition of phytoplankton populations responds to the ocean circulation.

\section{V.- CONCLUSIONS}

Phytoplankton pigment data collected along quarterly GeP\&CO cruises from the eastern north Atlantic to the south western tropical Pacific show patterns which clearly correspond to well-known seasonal or regional variability. Global biogeochemical models often include two categories of phytoplankton, i. e. large (diatoms) or small (Lancelot et al., 2000; Aumont et al., 2003; Fasham et al., 2005). This distinction indeed is needed to better represent the differences between areas where export production is rapid and intense and 
those where most of the primary production is recycled within the photic layer. The classification developed here, in which the fucoxanthin-rich clusters found in the north Atlantic and at the equator are placed close together, and well separated from the oligotrophic clusters (Figure 2), accounts for this major difference. Additionally, it also points on second order differences which, in most cases have a well marked geographical or seasonal signature. Major biogeochemical issues such as the occurrence of biocalcifying coccolithophores, or diazotrophic Trichodesmium, have been missed by this large-scale GeP\&CO sampling. Some GeP\&CO observations with highest fucoxanthin concentration proved however useful to identify diatoms from space (Alvain et al., 2005), but most of the fucoxanthin-rich samples that were encountered had chlorophyll concentrations lesser than $1 \mu \mathrm{g}^{-1}$, and thus did not correspond to the extremely rich diatoms blooms that massively export carbon to depth. This illustrates the difficulty to observe the sudden and important biogeochemical events, which often occur in restricted areas and have a short life. However, given that this work is based on eight cruises in two years, one can consider that it represents some of the main oceanic features and their seasonal cycles. Allocation of four clusters to oligotrophic conditions, mostly in the South Pacific Subtropical Gyre, where the dominant pigments are divinyl chlorophyll $a$, zeaxanthin and phycoerythrin, undoubtedly results from an ecosystem dominated by picophytoplankton (i. e. Prochlorococcus and Synechococcus). It is much more difficult to explain the subtle changes in phytoplankton populations that may force the differences between the clusters that dominated in the HNLC waters from the equatorial Pacific or in the waters that are not permanently oligotrophic. These clusters are characterized either by some relatively abundant carotenoids, or by monovinyl chlorophyll $b$ or chlorophyll $c$, which are generally indicative of poorly known pico- or nanoeucaryotes. For instance, the \#SBSEC cluster that focused on the nutrient-rich waters south of the equator in the Pacific Ocean had a pigment composition that departed noticeably from the GeP\&CO average by 
relatively high monovinyl chlorophyll $b$ and violaxanthin, indicating that some chlorophytes and/or prasinophytes were especially successful in this HNLC system; what triggered their growth is still unknown. We lack series of observations with accurate determinations of phytoplanktonic pico- or nanoeucaryotes in which the response to environmental changes could be related to population changes. Identifying these algae is still a difficult task which can hardly be undertaken routinely on a large scale. Some phytoplankton pigments are diagnostic pigments for groups of microalgae, but this permits only rough approximations of the phytoplankton composition. The case of pico- and nanoeucaryotes is especially complex. Algal classes often tend to colonize all kinds of environments while retaining their pigments characteristics (e. g. the ubiquitous 19' hexanoyloxyfucoxanthin). Better understanding of patterns such as those evidenced in this work in the tropical Pacific zonal current system, or as the plankton succession in temperate waters, requires improved methods to routinely identify the main taxa of the phytoplankton populations.

Acknowledgements : Thanks are due to the Owner, Captains and crews of MS Contship London, and to Mrs Downey at MCC Marine Consulting \& Contracting Gmbh in Hamburg, who kindly facilitated the boarding and tasks of the observers. These, Yves Montel, Joël Orempuller, François Baurand, Rémy Chuchla, Philippe Gérard and Denis Diverrés, made their best to ensure the conditioning of samples and the quality of measurements. We also thank the reviewers and the editor for their useful comments. Awa Niang benefited from grants from IRD and CNRS. 


\section{References}

Alvain, S., Moulin, C., Dandonneau, Y., Breon, F.-M., 2005. Remote sensing of phytoplankton groups in case I waters from global SeaWiFS imagery. Deep Sea Research Part I 52, 1989-2004.

Antoine, D., André, J.-M., Morel, A., 1996. oceanic primary production. 2. Estimation at global scale from satellite (coastal zone color scanner) chlorophyll. Global Biogeochemical Cycles 10, 57-69.

Aumont, O., Maier-Reimer, E., Blain, S., Monfray, P., 2003. An ecosystem model of the global ocean including Fe, Si, P colimitations. Global Biogeochemical Cycles 17, 1060, doi:10.1029/2001GB001745.

Barlow, R.G., Mantoura, R.F.C., Gough, M.A., Fileman, T.W., 1993. Pigments signatures of the phytoplankton composition in the northeastern Atlantic during the 1990 spring bloom. Deep-Sea Research part II 40, 459-477.

Blain, S., Tréguer, P., Rodier, M., 1999. Stocks and fluxes of biogenic silica in the western oligotrophic equatorial Pacific. Journal of Geophysical Research 104, 3357-3367.

Calbet, A.,Landry, M.R., 1999. Mesozooplankton Influences on the Microbial Food Web: Direct and Indirect Trophic Interactions in the Oligotrophic Open Ocean . Limnology and Oceanography 44, 1370-1380.

Capone, D.G., Zehr, J., Paerl, H.W., Bergman, B., Carpenter, E.J., 1997. Trichodesmium, a globally significant marine cyanobacterium. Science 276, 1221-1229.

Chavez, F., 1989. Size distribution of phytoplankton in the central and eastern tropical Pacific. Global Biogeochemical Cycles 3, 27-35.

Dandonneau, Y., Montel, Y., Blanchot, J., Giraudeau, J., Neveux, J., 2006. Temporal variability in phytoplankton pigments, picoplankton and coccolithophores along a transect through the North Atlantic and tropical southwestern Pacific. Deep Sea Research Part I 53, 
$689-712$.

Dugdale, R.C.,Goering, J.J., 1967. Uptake of new and regenerated forms of nitrogen in primary productivity. Limnology and Oceanography 12, 196-206.

Fasham, M.J.R., Flynn, K.J., Pondaven, P., Anderson, T.R., Boyd, P.W., 2005. Development of a robust marine ecosystem model to predict the role of iron in biogeochemical cycles: A comparison of results for iron-replete and iron-limited areas, and the SOIREE ironenrichment experiment. Deep Sea Research Part I 53, 333-366.

Fernandez, E.E., Maranon, E., Balch, W.M., 1996. Intracellular carbon partitioning in the coccolithophore Emiliana Huxleyi. Journal of Marine Systems 9, 57-66.

Gibb, S.W., Barlow, R.G., Cummings, D.G., Rees, N.W., Trees, C.C., Holligan, P., Suggett, D., 2000. Surface phytoplankton pigment distributions in the Atlantic Ocean: an assessment of basin scale variability between $50^{\circ} \mathrm{N}$ and $50^{\circ} \mathrm{S}$. Progress In Oceanography $45,339-368$.

Gibb, S.W., Cummings, D.G., Irigoien, X., Barlow, R.G., Mantoura, R.F.C., 2001. Phytoplankton pigment chemotaxonomy of the Northeast Atlantic. Deep-Sea Research part II $48,795-823$.

Goericke, R., Repeta, D. J., 1993. Chlorophylls a and b and divinyl chlorophylls a and b in the open subtropical North Atlantic Ocean. Marine Ecology Progress Series 1001 : 307-313.

Holligan, P.M., Fernandez Emilio, Aiken, J., Balch, W.M., Boyd, P., Burkill, P.H., Finch, M., Groom, S.B., Malin, G., Muller, K., Purdie, D.A., Robinson, C., Trees, C.C., Turner, S.M., van der Wal, P., 1993. A biogeochemical study of the coccolithophore ,Emiliania huxleyi, in the North Atlantic. Global Biogeochemical Cycles 7, 879-900.

Hood, R.R., Laws, E.A., Armstrong, R.A., Bates, N.R., Brown, C.W., Carlson, C.A., Chai, F., Doney, S.C., Falkowski, P.G., Feely, R.A., 2006. Pelagic functional group modelling: Progress, challenges and prospects. Deep Sea Research Part II 53, 459-512. 
Jeffrey, S.W.,Vesk, M., 1997. Introduction to marine phytoplankton and their pigment signatures. in : Jeffrey, S. W., Mantoura, R. F. C. and Wright, S. W. eds., Phytoplankton pigments in oceanography: guidelines to modern methods, Monographs on oceanographic methodology, SCOR-UNESCO, Paris, pp 37-84.

Jeffrey, S.W., Mantoura, R. F. C. and Bjornland, T. 1997. Data for the identification of 47 key phytoplankton pigments. in : Jeffrey, S. W., Mantoura, R. F. C. and Wright, S. W. eds., Phytoplankton pigments in oceanography: guidelines to modern methods, Monographs on oceanographic methodology, SCOR-UNESCO, Paris, pp 449-559.

Kana, T.M.,Glibert, P.M., 1987. Effects of irradiances up to $2000 \mu \mathrm{E} \mathrm{m}^{-2} \mathrm{~s}^{-1}$ on marine Synechococcus WH7803 - I. Growth, pigmentation, and cell composition. Deep-Sea Research 34, 479-495.

Kobayashi, F.,Takahashi, K., 2002. Distribution of diatoms along the equatorial transect in the western and central Pacific during the 1999 La Niña conditions. Deep-Sea Research part II 49, 2801-2821.

Kohonen, T., 2001. Self-organizing maps, (3rd edition), Springer, Berlin, 501 pp.

Lancelot, C., Hannon, E., Becquevort, S., Veth, C., DeBaar, H.J.W., 2000. Modelling phytoplankton blooms and carbon export production in the Southern Ocean : Dominant controls by light and iron in the Atlantic sector in Austral spring 1992. Deep-Sea Research part I 47, 1621-1662.

Landry, M.R., Barber, R.T., Bidigare, R.R., Chai, F., Coale, K.H., Dam, H.G., Lewis, M.R., Lindley, S.T., McCarthy, J.J., Roman, M.R., Stoecker, D.K., Verity, P.G., White, J.R., 1997. Iron and grazing constraints on primary production in the central equatorial Pacific : an EqPac synthesis. Limnology and Oceanography 42, 405-418.

Lantoine, F.,Neveux, J., 1997. Spatial and seasonal variations in abundance and spectral characteristics of phycoerythrins in the tropical Northeastern Atlantic ocean. Deep-Sea 
Research I 44, 223-246.

Latasa, M., Landry, M.R., Schlüter, L., Bidigare, R.R., 1997. Pigment-specific growth and grazing rates of phytoplankton in the central equatorial Pacific. Limnology and Oceanography 42, 289-298.

Le Quéré, C.S., Harrison, P., Prentice, I.C., Buitenhuis, E.T., Aumont, O., Bopp, L., Claustre, H., Cotrim da Cunha, L., Geider, R., Giraud, X., Klaas, C., Kohfeld, K.E., Legendre, L., M. Manizza, M., Platt, T., Rivkin, R.B., Sathyendranath, S., Uitz, J., Watson, A.J., WolfGladrow, D., 2005. Ecosystem dynamics based on plankton functional types for global ocean biogeochemistry models. Global Change Biology 11, 2016-2040.

Litchman, E., Klausmeier, C.A. , Miller, J.R., Schofield, O.M., Falkowski, P.G., 2006. Multinutrient, multi-group model of present and future oceanic phytoplankton communities. Biogeosciences 3, 585-606.

Longhurst, Alan., 1998. Ecological geography of the sea. Academic Press, London, 398 p. Mackey, D.J., Blanchot, J., Higgins, H.W., Neveux, J., 2002. Phytoplankton abundances and community structure in the equatorial Pacific. Deep-Sea Research part II 49, 2561-2582.

Mackey, M.D., Mackey, D.J., Higgins, H.W., Wright, S.W., 1996. CHEMTAX - a program for estimating class abundances from chemical markers : application to HPLC measurements of phytoplankton. Marine Ecology Progress Series 144, 265-283.

Menkes, C.E., Kennan, S.C., Flament, P., Dandonneau, Y., Masson, S., Biessy, B., Marchal, E., Eldin, G., Grelet, J., Montel, Y., Morlière, A., Lebourges-Dhaussy, A., Moulin, C., Champalbert, G., Herbland, A., 2002. A whirling ecosystem in the equatorial Atlantic. Geophysical Research Letters 29. doi : 10.1029/2001GL014576.

Neveux, J., Lantoine, F., 1993. Spectrofluorometric assay of chlorophylls and phaeopigments using the least squares approximation technique. Deep-Sea Research 40, 1747-1765.

Niang, A., Gross, L., Moulin, C., Badran, F., Thiria, S., 2003. Classification Automatique 
Neuronale de Reflectances Satellitaires (Niveau L1 B) de la Couleur de l'Ocean.

Télédétection 3, 337-364.

Partensky, F., Blanchot, J., Vaulot, D., 1999a. Differential distribution and ecology of Prochlorococcus and Synechococcus in oceanic waters : A review. Bulletin de l'Institut Océanographique, Monaco, spécial issue $\mathrm{n}^{\circ} 19$.

Partensky, F., Hess, W.R., Vaulot, D., 1999b. Prochlorococcus, a marine photosynthetic Procaryote of global significance. Microbiology and Molecular Biology Reviews 63, 106127.

Penno, S., Campbell, L., Hess, W.R., 2000. Presence of phycoerythrin in two strains of Prochlorococcus (cyanobacteria) isolated from the subtropical north pacific Ocean. Journal of Phycology 36, 723-729.

Romero, O. E., Hebbeln, D., Wefer, G., 2001. Temporal and spatial variability in export production in the SE Pacific Ocean : Evidence from siliceous plankton fluxes and surface sediment assemblages. Deep-Sea Research Part I 48, 2673-2697.

Wyman, M., 1992. An in vivo method for the estimation of phycoerythrin concentrations in marine cyanobacteria (Synechococcus spp.). Limnology and Oceanography 37, 1300-1306. 
Table 1 : Abbreviations of pigment names following Jeffrey et al. (1997). Asterisks refer to biomass-free normalized pigments

Abbreviation

Chl $a$, Chl $a^{*}$

$\mathrm{DV} \operatorname{chl} a, \mathrm{DV} \operatorname{chl} a^{*}$

Chl $b$, Chl $b^{*}$

$\mathrm{DV} \operatorname{chl} b, \mathrm{DV} \operatorname{chl} b^{*}$

Chl $c_{1+2}$, Chl $c_{1+2} *$

$\mathrm{Chl} c_{3}$, Chl $c_{3}$

Perid, Perid*

Fuco, Fuco*

But-fuco, But-fuco*

Hex-Fuco, Hex-Fuco*

Pras, Pras*

Viola, Viola*

Diadino, Diadino*

Allo, Allo*

Zea, Zea*

$\beta \beta$-car, $\beta \beta$-car*

Phycoer, Phycoer*

TChl $a$
Pigment name

Monovinyl chlorophyll $a$

Divinyl chlorophyll $a$

Monovinyl chlorophyll $b$

Divinyl chlorophyll $b$

Chlorophyll c1 + Chlorophyll $c_{2}$

Chlorophyll $c_{3}$

Peridinin

Fucoxanthin

19'-Butanoyloxyfucoxanthin

19'-Hexanoyloxyfucoxanthin

Prasinoxanthin

Violaxanthin

Diadinoxanthin

Alloxanthin

Zeaxanthin

$\beta \beta$-Carotene

Phycoerythrin

Monovinyl chlorophyll $a+$ divinyl chlorophyll $a$ 
Table 2 : Average values of normalized pigments concentrations for the ten clusters of observations. Bold characters indicate the largest deviations from the whole dataset average (absolute value greater than 0.5 ).

\#UM \#SGS \#EU \#SEC \#SG \#NAWSU \#UO \#SBSEC \#SGW \#NAWSp

\begin{tabular}{|c|c|c|c|c|c|c|c|c|c|c|}
\hline $\mathrm{Chl} a^{*}$ & 0.51 & -0.45 & 0.47 & -0.38 & -1.02 & 1.26 & -0.95 & -0.58 & -1.15 & 1.35 \\
\hline DV chl $a^{*}$ & -0.51 & 0.45 & -0.47 & 0.38 & 1.02 & -1.26 & 0.95 & 0.58 & 1.15 & -1.35 \\
\hline $\mathrm{Chl} b^{*}$ & -0.37 & -0.75 & 0.95 & 0.52 & -0.78 & 0.13 & -0.81 & 1.59 & -0.99 & 0.45 \\
\hline DV chl $b^{*}$ & 0.28 & 0.21 & -0.78 & 0.01 & 1.01 & -0.80 & 0.10 & -0.82 & 1.53 & -0.74 \\
\hline $\mathrm{Chl} \mathrm{Cl+2}^{*}$ & -0.15 & -0.75 & 0.85 & -0.02 & -0.90 & 1.10 & -0.85 & 0.31 & -0.54 & 0.62 \\
\hline $\mathrm{Chl} c_{3}$ & -0.06 & -0.20 & -0.18 & -0.16 & -0.16 & 1.12 & -0.23 & -0.23 & -0.23 & -0.02 \\
\hline erid* & 0.13 & -0.34 & 0.16 & 0.05 & -0.31 & 0.49 & -0.42 & 0.43 & -0.38 & -0.21 \\
\hline Fuco* & 0.12 & -0.37 & 0.21 & -0.21 & -0.44 & 0.62 & -0.31 & -0.21 & -0.56 & 0.81 \\
\hline But-Fuco* & 0.00 & -0.42 & 0.38 & 0.00 & -0.26 & 0.62 & -0.47 & -0.03 & -0.41 & 0.27 \\
\hline Hex-Fuco* & 0.06 & -0.29 & 0.34 & -0.06 & -0.22 & 0.48 & -0.45 & 0.53 & -0.38 & -0.28 \\
\hline Pras* & -0.13 & -0.25 & 0.00 & 0.62 & -0.18 & 0.11 & -0.25 & -0.21 & -0.20 & 0.24 \\
\hline Viola* & -0.22 & -0.45 & 0.48 & 0.02 & -0.48 & -0.11 & -0.37 & 1.29 & -0.46 & 0.46 \\
\hline Diadino* & 0.10 & -0.07 & 0.06 & -0.11 & -0.04 & 0.40 & -0.36 & 0.11 & -0.32 & -0.04 \\
\hline Allo* & 0.19 & -0.21 & -0.14 & -0.11 & -0.14 & 0.05 & -0.19 & -0.11 & -0.16 & 0.56 \\
\hline Zea* & -0.28 & 1.27 & -0.45 & 0.10 & 0.97 & -1.10 & 0.49 & 0.31 & 0.61 & -1.16 \\
\hline$\beta \beta-$ car $^{*}$ & -0.07 & 0.22 & -0.49 & 0.20 & 0.85 & -0.98 & 0.68 & 0.29 & 0.39 & -0.74 \\
\hline Phycoer* & -0.01 & 2.00 & -0.56 & -0.33 & 0.38 & -0.78 & 0.20 & -0.11 & 0.55 & -0.75 \\
\hline
\end{tabular}


Table 3 : Summary of clusters characteristics. Bold or italicized: pigments for which the average value of normalized concentrations (see table 2) is greater than 0.75 or lesser than 0.75 , respectively. Upward / downward arrows indicate algal groups that are likely to be above / below their GeP\&CO average (according to Gibb et al., 2000) cluster designation $\begin{gathered}\text { Pigments } \\ \text { characteristics }\end{gathered}$

\#UM $\quad \begin{gathered}\text { Undefined } \\ \text { mesotrophic }\end{gathered}$

\#EU

Equatorial $\quad \mathbf{C h l} b \mathbf{C h l} c_{1+2}$

\section{Zea Phycoer}

Chl b Chl $c_{1+2}$ in summer

upwelling

DV chlb

\#SEC South equatorial

current

none

\section{DV chl $a$ DV $\operatorname{chl} b$}

Zea

\#SG Subtropical gyre

north Atlantic

\#NAWSu bloom winter to summer

\#UO

$$
\begin{gathered}
\text { Undefined } \\
\text { oligotrophic }
\end{gathered}
$$

South branch of

\#SBSEC South Equatorial Current

\#SGW

Subtropical gyre in winter

\#NAWSp $\beta$ - $\beta$ car

$C h l$ a $C h l$ b

Chl $\mathrm{c}_{1+2}$

Chl $a$ Chl $c_{1+2}$

$\mathrm{Chl} c_{3}$

$D V \operatorname{chl}$ a $D V \operatorname{chl} \mathrm{b}$

Zea $\beta \beta$-car

Phycoer

DV chl a $\beta \boldsymbol{\beta}$-car

$C h l$ a $C h l$ b

Chl $c_{1+2}$

Chl $b$ Viola

DV chlb

DV chl $a$ DV chl $b$

Chlor a Chlor b

Chlor $\boldsymbol{a}$ Fuco

DV chl a Zea

Phycoer
Synechococcus $\uparrow$ chlorophytes $\downarrow$ prasinophytes $\downarrow$ diatoms $\downarrow$ haptophytes $\downarrow$ dinoflagellates $\downarrow$ pelagophytes $\downarrow$ cryptophytes $\downarrow$

diatoms $\uparrow$ chlorophytes $\uparrow$ haptophytes $\uparrow$ prasinophytes $\uparrow$ dinoflagellates $\uparrow$ pelagophytes $\uparrow$ cryptophytes $\uparrow$

Prochlorococcus $\downarrow$
Prochlorococcus $\uparrow$ diatoms $\downarrow$ haptophytes $\downarrow$ dinoflagellates $\downarrow$ pelagophytes $\downarrow$ cryptophytes $\downarrow$

diatoms $\uparrow$ haptophytes $\uparrow$ pelagophytes $\uparrow$ dinoflagellates $\uparrow$ cryptophytes $\uparrow$ Prochlorococcus $\downarrow$ Synechococcus $\downarrow$

Prochlorococcus $\uparrow$ chlorophytes $\downarrow$ prasinophytes $\downarrow$ diatoms $\downarrow$ haptophytes $\downarrow$ dinoflagellates $\downarrow$ pelagophytes $\downarrow$ cryptophytes $\downarrow$

chlorophytes $\uparrow$ prasinophytes $\uparrow$ Prochlorococcus $\downarrow$

Prochlorococcus $\uparrow$ chlorophytes $\downarrow$ prasinophytes $\downarrow$

diatoms $\uparrow$ Prochlorococcus $\downarrow$ Synechococcus $\downarrow$ 
Table 4 : Range of marine properties for the pigments-based clusters (in each cell, from top to bottom : first quartile, median, and third quartile)

\begin{tabular}{|c|c|c|c|c|c|c|c|c|c|c|c|}
\hline cluster & all & \#UM & \#SGS & \#EU & \#SEC & \#SG & $\begin{array}{l}\text { \#NA } \\
\text { WSu }\end{array}$ & \#UO & $\begin{array}{l}\text { \#SB } \\
\text { SEC }\end{array}$ & \#SGW & $\begin{array}{l}\text { \#NA } \\
\text { WSp }\end{array}$ \\
\hline \multirow{3}{*}{$\begin{array}{l}\text { TChla } \\
\left(\mu \mathrm{g} \mathrm{L}^{-1}\right)\end{array}$} & 0.092 & 0.087 & 0.038 & 0.174 & 0.139 & 0.070 & 0.261 & 0.098 & 0.112 & 0.079 & 0.253 \\
\hline & 0.154 & 0.196 & 0.048 & 0.222 & 0.191 & 0.088 & 0.332 & 0.111 & 0.132 & 0.089 & 0.672 \\
\hline & 0.284 & 0.382 & 0.062 & 0.274 & 0.255 & 0.129 & 0.731 & 0.131 & 0.148 & 0.098 & 0.872 \\
\hline \multirow{3}{*}{$\begin{array}{l}\text { Picoeu } \\
\text { caryotes } \\
(\text { cells } / \mathrm{mL})\end{array}$} & 810 & 562 & 427 & 2572 & 2463 & 810 & 2505 & 562 & 3084 & $J$ & 3288 \\
\hline & 2485 & 1084 & 711 & 4875 & 4640 & 2213 & 4431 & 807 & 4067 & 739 & 5382 \\
\hline & 6086 & 3718 & 1057 & 7337 & 8305 & 6863 & 10444 & 1224 & 5736 & 1096 & 14722 \\
\hline \multirow{3}{*}{$\begin{array}{l}\text { Synecho } \\
\text { coccus } \\
\text { (cells } / \mathrm{mL})\end{array}$} & 1805 & 3357 & 355 & 4943 & 6432 & 343 & 4982 & 1345 & 6551 & 460 & 7485 \\
\hline & 6659 & 6557 & 873 & 9314 & 9954 & 1644 & 10838 & 3006 & 7756 & 782 & 12171 \\
\hline & 14188 & 20698 & 1959 & 22032 & 17184 & 4353 & 28781 & 8356 & 10022 & 3967 & 31456 \\
\hline \multirow{3}{*}{$\begin{array}{l}\text { Prochlo } \\
\text { rococcus } \\
\left(10^{3}\right. \\
\text { cells } / \mathrm{mL})\end{array}$} & 30 & 20 & 55 & 34 & 81 & 67 & 5 & 76 & 76 & \multirow{3}{*}{$\begin{array}{l}6497 \\
120\end{array}$} & 3 \\
\hline & 77 & 33 & 84 & 63 & 109 & 104 & 16 & 114 & 96 & & 4 \\
\hline & 115 & 78 & 117 & 84 & 146 & 126 & 48 & 140 & 127 & & 8 \\
\hline \multirow{3}{*}{$\begin{array}{l}\text { Heterotr. } \\
\text { Bacteria } \\
\left(10^{3}\right. \\
\text { cells } / \mathrm{mL})\end{array}$} & 311 & 231 & 330 & 472 & 409 & 379 & 295 & 238 & 385 & 191 & 348 \\
\hline & 429 & 379 & 408 & 643 & 590 & 433 & 484 & 353 & 516 & 302 & 427 \\
\hline & 645 & 765 & 492 & 805 & 716 & 517 & 727 & 447 & 642 & 387 & 662 \\
\hline \multirow{3}{*}{$\begin{array}{l}\text { Nitrate } \\
(\mu \mathrm{M})\end{array}$} & 0.07 & 0.06 & 0.04 & 2.29 & 0.15 & 0.05 & 0.25 & 0.03 & 3.47 & 0.02 & 1.29 \\
\hline & 0.50 & 0.19 & 0.06 & 5.79 & 1.31 & 0.11 & 2.44 & 0.06 & 4.97 & 0.09 & 2.73 \\
\hline & 3.90 & 1.31 & 0.11 & 7.85 & 6.20 & 0.17 & 5.02 & 0.20 & 6.48 & 0.27 & 4.77 \\
\hline \multirow{3}{*}{$\begin{array}{l}\text { Phosphate } \\
(\mu \mathrm{M})\end{array}$} & 0.030 & 0.018 & 0.030 & 0.230 & 0.080 & 0.030 & 0.080 & 0.000 & 0.360 & $0 .($ & 0.095 \\
\hline & 0.124 & 0.060 & 0.070 & 0.452 & 0.230 & 0.060 & 0.160 & 0.010 & 0.440 & 0.079 & 0.160 \\
\hline & 0.185 & 0.140 & 0.130 & 0.590 & 0.440 & 0.150 & 0.270 & 0.034 & 0.550 & 0.140 & 0.230 \\
\hline \multirow{3}{*}{$\begin{array}{l}\text { Silicate } \\
(\mu \mathrm{M})\end{array}$} & 0.75 & 0.77 & 0.47 & 1.32 & 0.88 & 0.64 & 0.78 & 0.76 & 1.57 & 0.56 & 1.00 \\
\hline & 1.24 & 1.21 & 0.60 & 2.36 & 1.28 & 0.92 & 1.61 & 0.89 & 2.17 & 0.81 & 1.78 \\
\hline & 2.17 & 1.91 & 1.11 & 3.85 & 2.64 & 1.35 & 2.67 & 1.38 & 2.53 & 1.19 & 2.33 \\
\hline \multirow{3}{*}{$\begin{array}{l}\text { Tempera- } \\
\text { ture }\left({ }^{\circ} \mathrm{C}\right)\end{array}$} & 20.04 & 20.44 & 22.90 & 23.05 & 24.23 & 23.45 & 14.57 & 22.32 & 26.12 & 23.59 & 13.74 \\
\hline & 24.61 & 25.50 & 24.61 & 24.78 & 25.98 & 26.52 & 16.91 & 25.86 & 27.03 & 26.55 & 16.53 \\
\hline & 27.29 & 27.87 & 27.43 & 26.68 & 27.11 & 28.04 & 19.02 & 27.87 & 27.68 & 28.17 & 18.33 \\
\hline \multirow{3}{*}{ Salinity } & 35.0 & 34.74 & 35.39 & & 34.96 & 35.38 & 34.80 & 35.43 & 35.24 & 35.52 & 35.40 \\
\hline & & 35.65 & 35.49 & 34.98 & 35.28 & 35.66 & 35.64 & 35.69 & 35.51 & 35.90 & 35.84 \\
\hline & 35.96 & 36.28 & 35.63 & 35.21 & 35.83 & 36.02 & 35.92 & 36.15 & 35.76 & 36.21 & 36.15 \\
\hline
\end{tabular}




\section{FIGURE CAPTIONS}

Figure 1: Geographical and seasonal distribution of the ten clusters resulting from the classification of the normalized GeP\&CO pigment concentration data.

Figure 2 : Dendrogram of the GeP\&CO observations. Space and time attributes in clusters names have been given according to Figure 1 .

Figure 3 : Comparison of the normalized properties of \#NAWSu and \#NAWSp (north Atlantic bloom, winter to summer and winter to spring). Squares and plain characters: average values of pigments used for the classification. Plus signs and italics: ancillary data.

Figure 4 : Comparison of the normalized properties of \#SGS and \#SGW (South Pacific Subtropical Gyre, in summer and winter). Squares and plain characters: average values of pigments used for the classification. Plus signs and italics: ancillary data.

Figure 5 : Comparison of the normalized properties of \#EU and \#SBSEC (equatorial upwelling and southern branch of South Equatorial Current). Squares and plain characters: average values of pigments used for the classification. Plus signs and italics: ancillary data. 

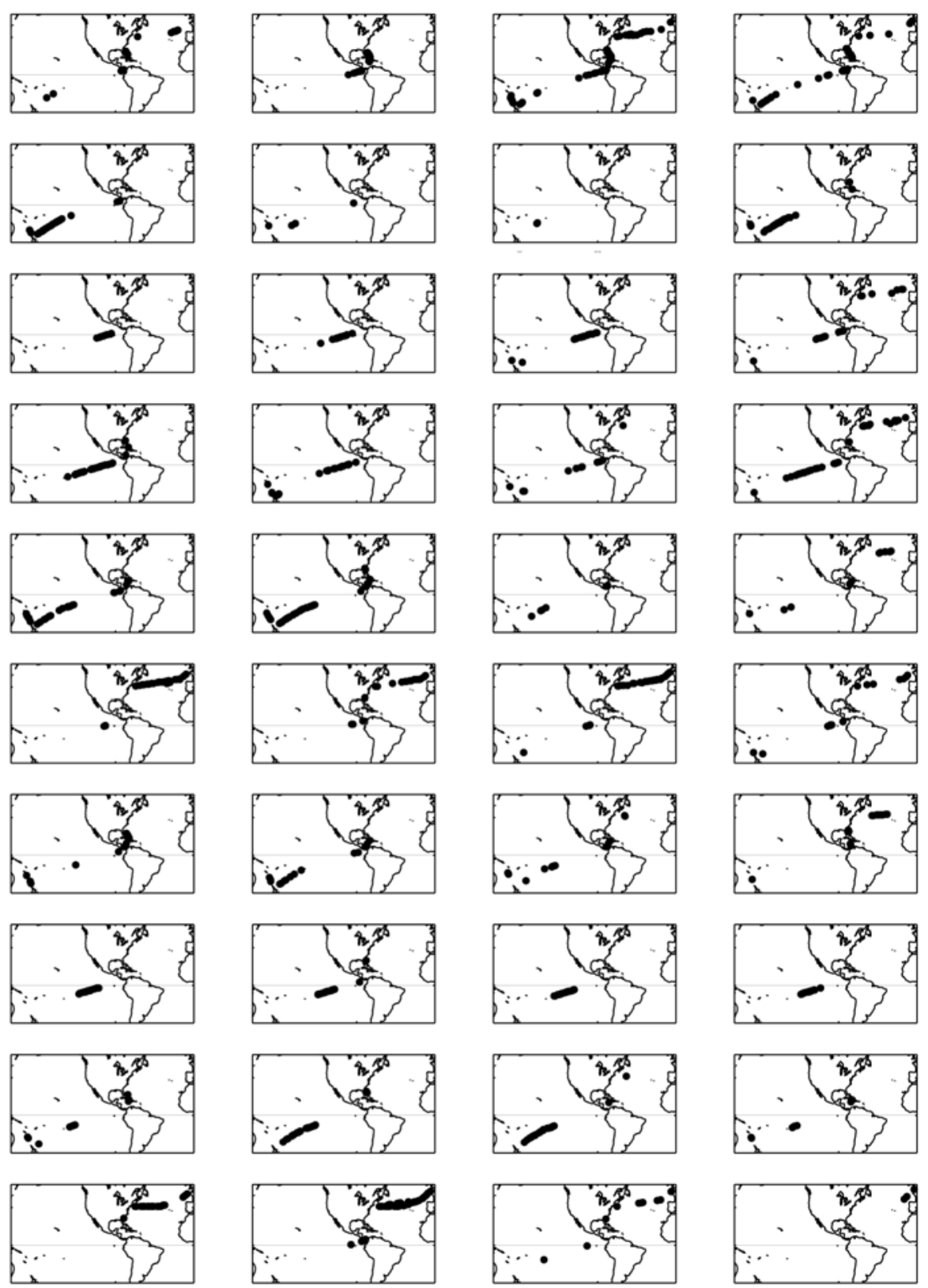

Figure 1 : Geographical and seasonal distribution of the ten clusters resulting from the classification of the normalized GeP\&CO pigments concentrations data. 


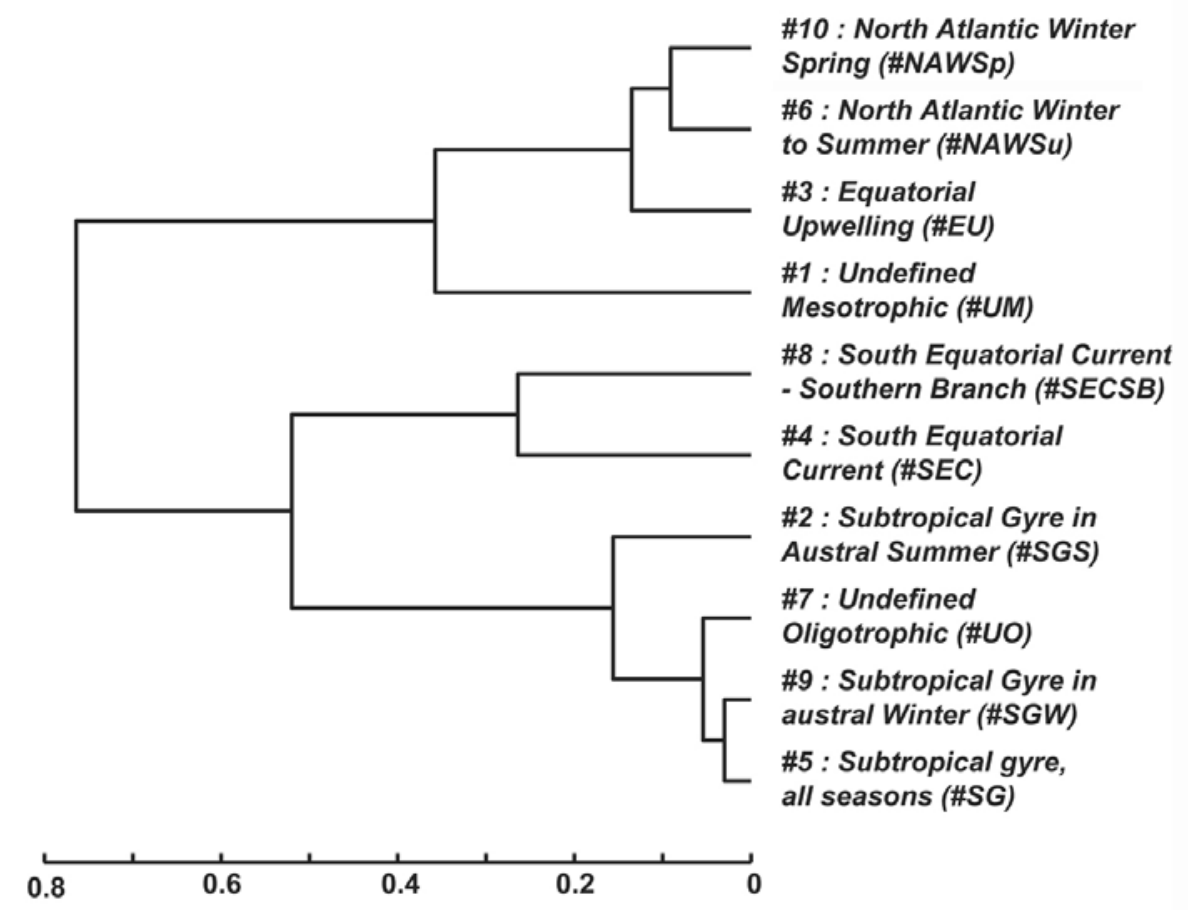

Figure 2 : Dendrogram of the GeP\&CO observations. Space and time attributes in clusters names have been given according to Figure 1 . 


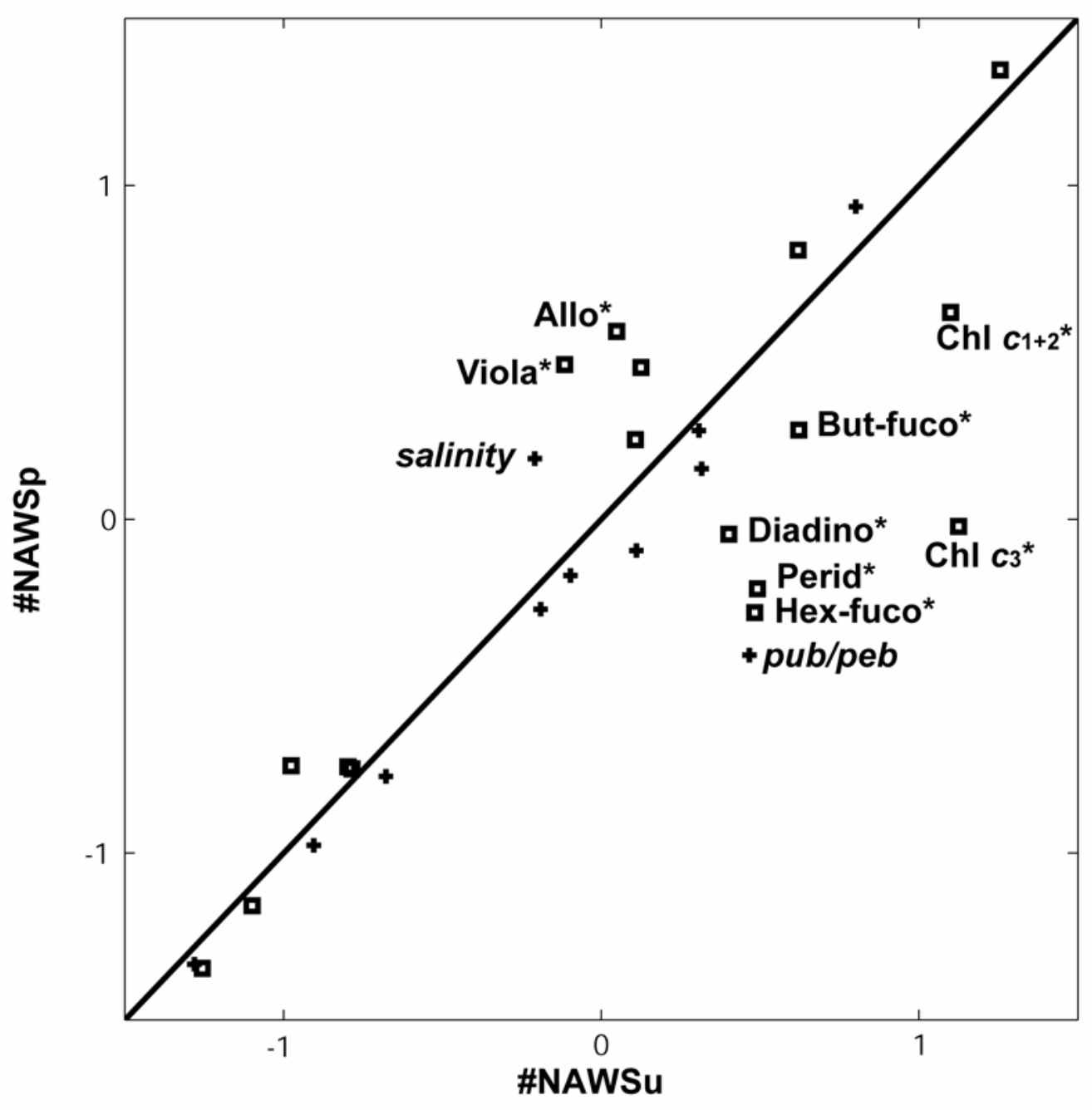

Figure 3 : Comparison of the normalized properties of \#NAWSu and \#NAWSp (north Atlantic bloom, winter to summer and winter to spring). Squares and plain characters: average values of pigments used for the classification. Plus signs and italics: ancillary data. 


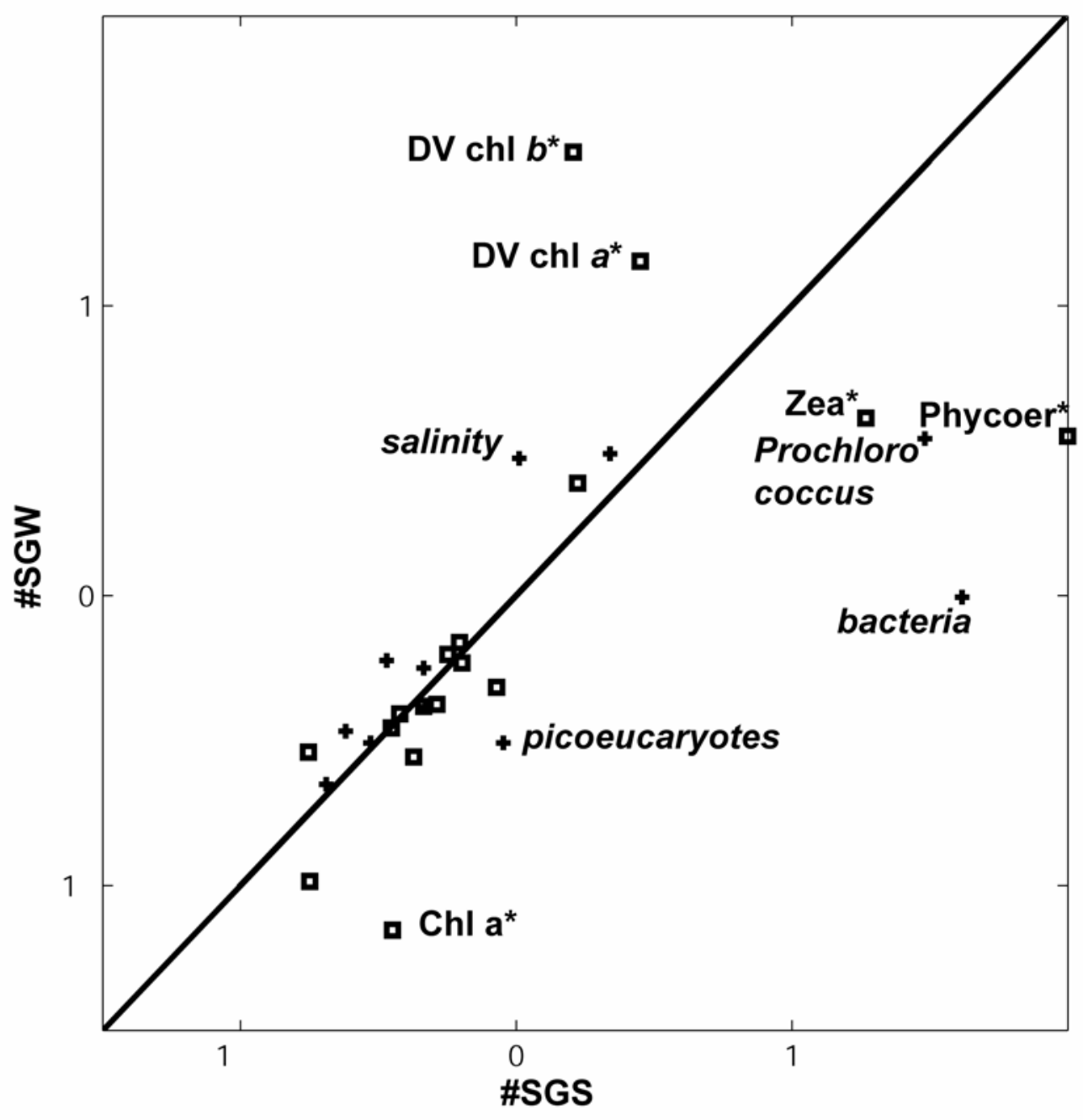

Figure 4 : Comparison of the normalized properties of \#SGS and \#SGW (south Pacific subtropical gyre, in summer and winter). Squares and plain characters: average values of pigments used for the classification. Plus signs and italics: ancillary data. 


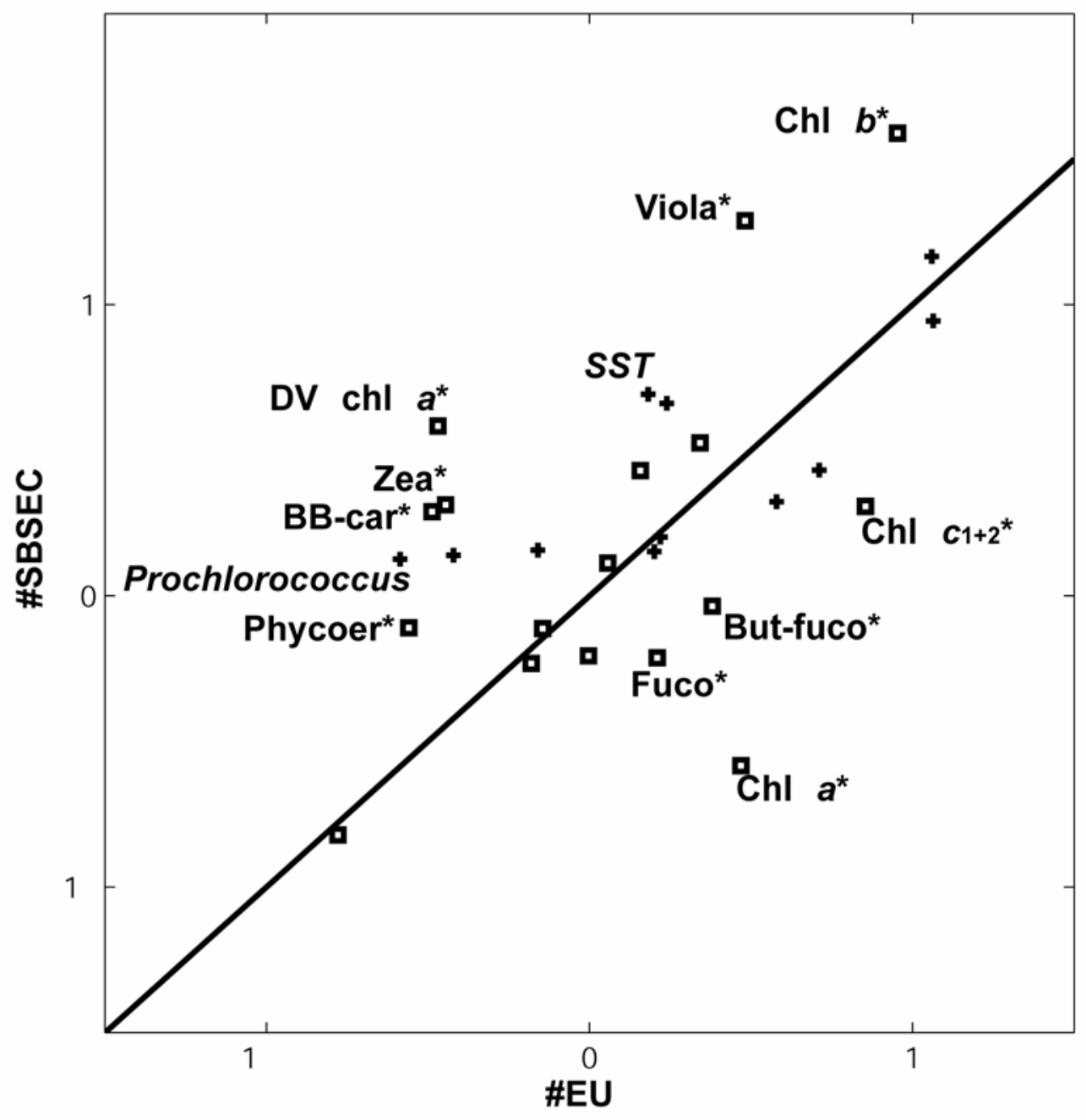

Figure 5 : Comparison of the normalized properties of \#EU and \#SBSEC (equatorial upwelling and southern branch of South Equatorial Current). Squares and plain characters: average values of pigments used for the classification. Plus signs and italics: ancillary data. 